\title{
SURVEY TINGKAT PENGETAHUAN MEMBER FITNESS KOTA MEDAN DALAM MENGKONSUMSI SUPLEMEN
}

\author{
Oleh \\ Frenki Franata Saragih ${ }^{1}$, Mesnan ${ }^{2}$ \\ ${ }^{1}$ Fakultas Ilmu Keolahragaan Universitas Negeri Medan \\ ${ }^{2}$ Fakultas Ilmu Keolahragaan Universitas Negeri Medan \\ Email: frenkifranata@gmail.com
}

\begin{abstract}
Abstrak
Tujuan penelitian ini adalah untuk mengetahui tingkat pengetahuan member fitness dalam mengonsumsi suplemen. Adapun tempat penelitian dilakukan di fitness center New Life Gym, X1 Fitness Center dan Olympus Gym Center di Kota Medan. Penelitian dimulai pada bulan Januari sampai dengan Maret 2016. Besar sampel penelitian yang didapat melalui purposive sampling adalah 80 orang. Jenis penelitian ini adalah penelitian survey deskriptif. Data penelitian dikumpulkan dengan menggunakan kuesioner yang didalamnya memuat beberapa kelompok pertanyaan mengenai: karakteristik|responden, pengetahuan, yang berhubungan dengan mengkonsumsi suplemen. Analisa data dilakukan dengan menggunakan program di komputer meliputi pemasukan data dan tabulasi data. Data yang dikumpulkan disajikan dalalm bentuk tabel distribusi frekuensi. Berdasarkan hasil penelitian maka didapat tingkat rata-rata pengetahuan member fitness centre di Kota Medan dalam mengonsumsi suplemen berada dalam kategori tinggi yaitu $84 \%$.
\end{abstract}

Kata Kunci: Tingkat pengetahuan, member fitness, suplemen.

\section{A. PENDAhuluan}

Di era modernisasi mengkonsumsi suplemen makanan seperti sebuah hal yang sudah dianggap kebutuhan bagi masyarakat ditengah-tengah mobilitas masyarakat yang semakin padat untuk menunjang aktifitas sehari-hari. Alasan waktu dan kepraktisan adalah alasan yang paling utama, sehingga suplemen makanan menjadi solusi andalan oleh masyarakat untuk memenuhi kebutuhan gizi secara instan tanpa harus repot mengatur waktu untuk memakan makanan sehat, olahraga teratur dan sebagainya. Semakin tingginya kesadaran masyarakat akan pentingnya kesehatan dan kecukupan zat gizi didalam tubuh sekaligus adanya kekhawatiran makanan yang di konsumsi tidak dapat memenuhi kebutuhan tubuh akan zat gizi menyebabkan produk suplemen makanan menjadi sangat laku di pasaran. Hampir semua lapisan masyarakat mengenal makanan tambahan atau yang lebih dikenal dengan food supplement. Meskipun penggunaan food supplement masih menjadi perdebatan dikalangan peneliti namun akhir-akhir ini penggunaan food supplement makin popular di berbagai lapisan masyarakat. 
Meski penggunaan food supplement menguntungkan bagi kesehatan dan kecantikan namun jika penggunaannya salah justru akan membahayakan kesehatan seseorang. Keinginan untuk mengkonsumsi produk yang praktis dan dapat melengkapi pemenuhan kebutuhan zat gizi yang belum seimbang menyebabkan permintaan terhadap produk suplemen makanan semakin meningkat (Gunawan, 1999:19). Penggunaan suplemen perlu memperhatikan aturan pakainya, Selain itu perlu diingat bahwa suplemen hanya berkhasiat pada mereka yang betul-betul memerlukan. Pemakaian suplemen protein pada atlet dipercaya dapat meningkatkan ukuran otot, sehingga kekuatan otot akan bertambah dân dapat mengurangi lemak tubuh.

Penggunaan ekstraprotein dapat berupa menambah bahan makanan sumber protein terutama protein hewani melebihi kebutuhan normal yang dianjurkan atau menggunakann jenis asam amino tertentu dalam bentuk tepung, dan yang perlu diperhatikan adalah bagaimana makanan tambahan tersebut aman dan baik untuk tubuh bukan sebaliknya. Dari hasil observasi awal yang dilakukan peneliti terhadap member di fitness center Hotel Danau Toba, bahwa sebagian besar membernya mengkonsumsi suplemen protein, dengan tujuan untuk membantu membentuk otot yang ideal. Dengan kenyataannya mereka tidak puas akan kondisi otot yang mereka dapatkan setelah mengkonsumsi suplemen protein.

Hal ini tentunya tidak dapat terlepas dari tingkat pengetahuan member terhadap seluk beluk suplemen dan mekanisme mengkonsumsi suplemen. Dalam penelitian ini, penulis ingin mengetahui tingkat pengetahuan member terhadap suplemen, mengenai alasan dan tujuan mengkonsumsi suplemen, jenis suplemen yang dikonsumsi, cara mengkonsumsi suplemen, cara mendapatkan suplemen, frekuensi konsumsi suplemen serta mitos dan efek yang dirasakan setelah mengkonsumsi suplemen.

\section{Pengetahuan}

Menurut Notoatmodjo (2010:1) mengatakan “Pengetahuan adalah hasil tahu dari manusia, yang sekedar menjawab pernyataan "what", misalnya apa air, apa alam dan sebagainya. Sedangkan ilmu (science) bukan sekedar menjawab "what", melainkan akan menjawab "why" dan "how", misalnya mengapa air mendidih bila dipanaskan, mengapa bumi berputar, mengapa manusia bernafas, dan sebagainya". Lebih lanjut lagi menurut Daryanto (2008: 103) mengatakan "pengetahuan adalah aspek yang paling dasar dalam taksonomi Bloom, seringkali disebut juga aspek ingatan (recall)". 


\section{Pengertian Suplemen}

BPOM (2004) mendefinisikan suplemen makanan sebagai produk yang dimaksudkan untuk melengkapi kebutuhan zat gizi makanan, mengandung satu atau lebih dari bahan berupa vitamin, mineral, asam amino atau bahan lain (berasal dari tumbuhan atau bukan tumbuhan) yang mempunyai nilai gizi dan efek fisiologis dalam jumlah terkonsentrasi. Suplemen makanan dapat berupa produk padat meliputi tablet, tablet hisap, tablet kunyah, serbuk, kapsul atau produk cair berupa tetes, sirup, larutan.

\subsection{Bahaya Suplemen Makanan}

Berikut merupakan beberapa dampak negatif penggunaan suplemen menurut Yuliarti (2008) adalah sebagai berikut:

a) Kelebihan vitamin $\mathrm{C}$ mungkin bisa dibuang lewat urin. Tetapi vitamin jenis lain (A, $\mathrm{D}$, E, dan K) umumnya mengendap di dalam tubuh dan di khawatirkan bisa mengganggu fungsi organ terutama hati dan ginjal.

b) Protein yang biasanya terdapat di suplemen bila dikonsumsi orang tertentu bisa menimbulkan efek alergi.

c) Konsumsi zat besi berlebihan tidak baik/untuk para penderita kelainan darah seperti thalassemia.

d) Konsumsi suplemen vitamin $\mathrm{K}$ pada orang yang tengah minum obat tertentu kadang-kadang justru memperburuk keadaan.

e) Suplemen yang mengandung hormone tambahan dikhawatirkan malah memicu gigantisme (tubuh menjadi sangat besar) dan gangguan seksual.

f) Konsumsi berlebihan suplemen antioksidan seperti viatamin A, E dan betakaroten justru meningkatkan risiko kematian.

g) Suplemen vitamin D berlebihan justru berbahaya bagi hati dan ginjal.

h) Mengkonsumsi suplemen berupa minuman berenergi dapat meningkatkan tekanan darah.

i) Suplemen herbal dan natural pengganti Viagra yang diklaim lebih aman juga mengandung bahaya seperti meningkatkan tekanan darah, bahkan mengakibatkan stroke.

j) Terlalu banyak mengkonsumsi vitamin $\mathrm{C}$ akan mengganggu penyerapan tembaga, yang meskipun dibutuhkan dalam jumlah sangat kecil, namun penting untuk mengatur susunan kimia dan kinerja tubuh.

k) Terlalu banyak suplemen mengandung fosfor akan menghambat penyerapan kalsium.

1) Kelebihan vitamin $\mathrm{A}, \mathrm{D}, \mathrm{K}$ dan zat besiyang tidak dapat dibuang tubuh berbalik menjadi racun.

Pada umumnya, suplemen makanan kesehatan berasal dari bahan-bahan alami tanpa bahan kimia (harus murni) dan merupakan saripati bahan makanan (konsentrat). Dalam pengobatan konvensional, yang dimaksud dengan suplemen adalah termasuk obat metabolisme untuk menghambat nafsu makan, obat untuk menurunkan lemak dan 
kolesterol, obat untuk memperbaiki status gizi, penyegar tubuh, pembangkit tenaga, dan obat untuk memperbaiki sistem metabolik organ tertentu. Sementara dari segi pengelompokannya, suplemen tersebut adalah vitamin, mineral, asam amino, enzim, hormon, antioksidan, herba, dan probiotik. Ada dalam bentuk sediaan tunggal atau kombinasi untuk mendapatkan efek pengobatan tertentu (Olivia dkk, 2006:26).

Manfaat suplemen adalah untuk menghindarkan kekurangan gizi akibat pola makan tidak teratur dan tidak sehat serta membantu mengembalikan vitalitas (Olivia dkk, 2006: 26). Menurut Irianto (2007: 12) berikut adalah hal-hal yang perlu dipertimbangkan tanpa kelelahan yang sèmestinya dan dengan cukup energi, sehingga tetap dapat menikmati waktu luang dan menanggulangi keadaan keadaan mendadak yang tidak diperkirakan. Berbagai studi ilmiah telah membuktikan dan menganjurkan latihan beban sebagai aktivitas yang berguna untuk: mencegah keropos tulang dan penyusutan tubuh pada orang-orang berusia lanjut, memperlambat proses penuaan, meningkatkan profil hormon dan libido, meningkatkan imunitas/ tubuh terhadap penyakit, mencegah dan mendukung terap terhadap penyakit pembunuh terbesar manusia: diabetes, stroke, penyakit jantung, dan kanker, meningkatkan performa atlit di berbagai cabang olahraga, memperlancar peredaran darah, nutrisi, dan oksigen ke seluruh tubuh.

Dalam membentuk tubuh yang ideal, dan berotot temasuk dalam dalam pembentukan six pack, kunci utama dalam keberhasilan pembentukan tubuh, program penurunan berat badan ada pada angkat beban pada pola latihan, karena terbentuknya otot akan meningkatkan kalori yang dibakar dalam seharinya sehingga lemak cepat berkurang dan badan lebih seksi dan berenergi. Hal ini berlaku untuk pria dan wanita. Dalam memasuki fitnes pada umumnya seseorang akan dihadapkan pada dua hal, yaitu pertama, program latihan dan teknik latihan yang benar, dan yang kedua adalah nutrisi, dalam hal ini yang akan dibahas dalam tulisan ini adalah nutrisi khususnya yang berhubungan dengan suplemen pembentukan otot yang sekarang sudah banyak beredar di pasaran dan mereknya mulai beragam. Berikut ini adalah suplemen pembentukan otot yang dapat membantu pembentukan otot yaitu protein powder, asam amino, weigh gainers, creatine powder, ZMA dan Prohormon (Daniel Adrian, 2014: 122). 


\section{Protein Powder}

Bubuk protein ini bisa digunakan untuk membuat minuman sehat, jus, bahkan kue dan roti berprotein tinggi yang sehat dikonsumsi. Bubuk protein yang terkenal yang ada dipasaran yang terbukti ampuh menambah massa otot antara lain adalah whey protein, casein, dan soy protein. Sementara whey sendiri terdiri lagi dari beberapa jenis yaitu: Whey Protein Concentrate (WPC), Ion Exchange Isolate, dan Cross Flow Microfiltered Whey.

\section{Asam Amino}

Ada sedikit perbedaan antara whey dan amino, amino lebih unggul dalam hal penyerapan dan pemanfaatan oleh tubuh, karena amino tidak lagi butuh proses cerna seperti whey, amino yang benar sudah melalui proses enxymatic digestion melalui proses tertentu sehingga ia siap serap, beda dengan whey yang harus dicerna dulu di perut. Dengan demikian amino sesungguhnya tepat dikonsumsi sebelum latihan dan sesudah latihan untuk menjaga dan memaintain massa otot, juga bisaldikonsumsi kapan saja pada waktu membutuhkan asupan proteindengan cepat dan praktis.

\section{Weight Gainers}

Penambah berat badan ini sesungguhnya kandungan utamanya adalah bubuk protein dikombinasikan dengan karbohidrat tinggi dan beberapa mineral penting untuk metabolism tubuh, yang penting perhatikan komposisi dari karbohidrat dan protein. Pada umumnya berat badan bertambah karena: a) bertambah lemak, b) bertambah otot, dan c) bertambah air. Faktor a dan b ini yang biasa terjadi pada orang yang bisa mengkonsumsi weight gainers. Keberadaan karbohidrat penting jika mau menambah otot, karena karbohidrat adalah sumber energi utama untuk latihan, dan memiliki efek muscle sparring, maksudnya, jika mengkonsumsi karbohidrat cukup maka tubuh tidak akan mengkanibal otot untuk dijadikan sumber energi.

\section{Creatine Powder}

Banyak orang menganggap fungsi creatin adalah sebagai pembesar otot, ini tidak salah namun kurang tepat. Sebenarnya fungsi kreatin adalah untuk meningkatkan power otot atau stamina otot, kreatin sanggup memperlama kontraksi otot sehingga performa latihan meningkat. Creatine akan memperbanyak produksi ATP, zat yang dapat meningkatkan lama kontraksi otot. Efek samping creatine adalah retensi air dimana sel otot akan menarik air ke dalam sel dan sekelilingnya sehingga sel membesar, 
efek pembesaran ini tidak permanen tetapi selama mengkonsumsi creatine, dan masih belum jelas apakah adanya retensi air akan meningkatkan sintesa protein di otot, oleh karena itu creatine dianggap sebagai performance enhancer daripada memperbesar otot.

\section{ZMA}

ZMA adalah suplemen yang bersifat spesifik isinya adalah kombinasi dosis tinggi antara vitamin B6, mineral zinc dan magnesium. Kombinasi ketiganya berdasarkan riset telah terbukti oleh para pemakai mampu meningkatkan hormon testosteron yang produksinya dapat ditingkatkan saat tertidur. ZMA biasanya juga mengandung zat yang meningkatkan kualitas tidur. Rekuperasi dan pertumbuhan otot bukan terjadi pada saat berlatih, tetapi pada saat tidur, pada saat inilah tubuh membutuhkan protein dalam jumlah banyak, sehingga segelas whey protein sebelum tidur atau sepotong dada ayam bisa meningkatkan potensi sintesa protein dan ditambah protein cukup menjelang tidur pada akhirnya perkembangan otot menjadi maksimal.

\section{Prohormon}

Prohormon salah satu zat ampuh yang mampu meningkatkan produksi otot, karena suplemen ini mengandung prekusor dari hormon testosterone. Hormon ini selain memberikan karakteristik pria atau andogenik, juga membuat tubuh menjadi anabolic, artinya tubuh akan meretensi nitrogen semaksimal mungkin untuk meningkatkan pembentukan otot tubuh. Prekuser artinya diharapkan setelah dikonsumsi tubuh akan mengkonversi zat ini menjadi hormone testosterone yang sesungguhnya.

\section{B. METODE PENELITIAN}

Penelitian dilaksanakan di kota Medan, yang mengambil tempat di fitness center Danau Toba, Hotel Tiara, dan Cleopatra. Waktu yang digunakan selama 4 bulan dari bulan Agustus - Nopember 2015. Populasi dalam penelitian ini adalah seluruh member fitnes kota Medan yang berada di fitness center Danau Toba, Hotel Tiara, dan Cleopatra yang berjumlah 100 orang. Alasan memilih ketiga tempat ini dikarenakan mudah dijangkau dan memberikan ijin untuk diteliti, yang menjadi sampel dalam penelitian ini adalah member fitnes kota Medan yang berada di fitness center Danau Toba, Hotel Tiara, dan Cleopatra. Teknik pengambilan sampel pada penelitian ini menggunakan purposive sampling yaitu dengan kriteria ekslusif:

1. Sampel mengonsumsi suplemen.

2. Bersedia menjadi sampel. 
Metode penelitian yang dipergunakan dalam penelitian ini adalah metode deskiptif dengan memberikan instrumen sebagai alat pengumpul data berupa angket kepada sampel. Instrumen yang digunakan dalam penelitian ini adalah angket yang berisi pernyataan tentang pengetahuan member fitnes mengenai suplemen. Adapun kisikisinya dapat dilihat pada tabel dibawahini

Tabel 1. Kisi-Kisi Tes Pengetahuan Tentang Suplemen

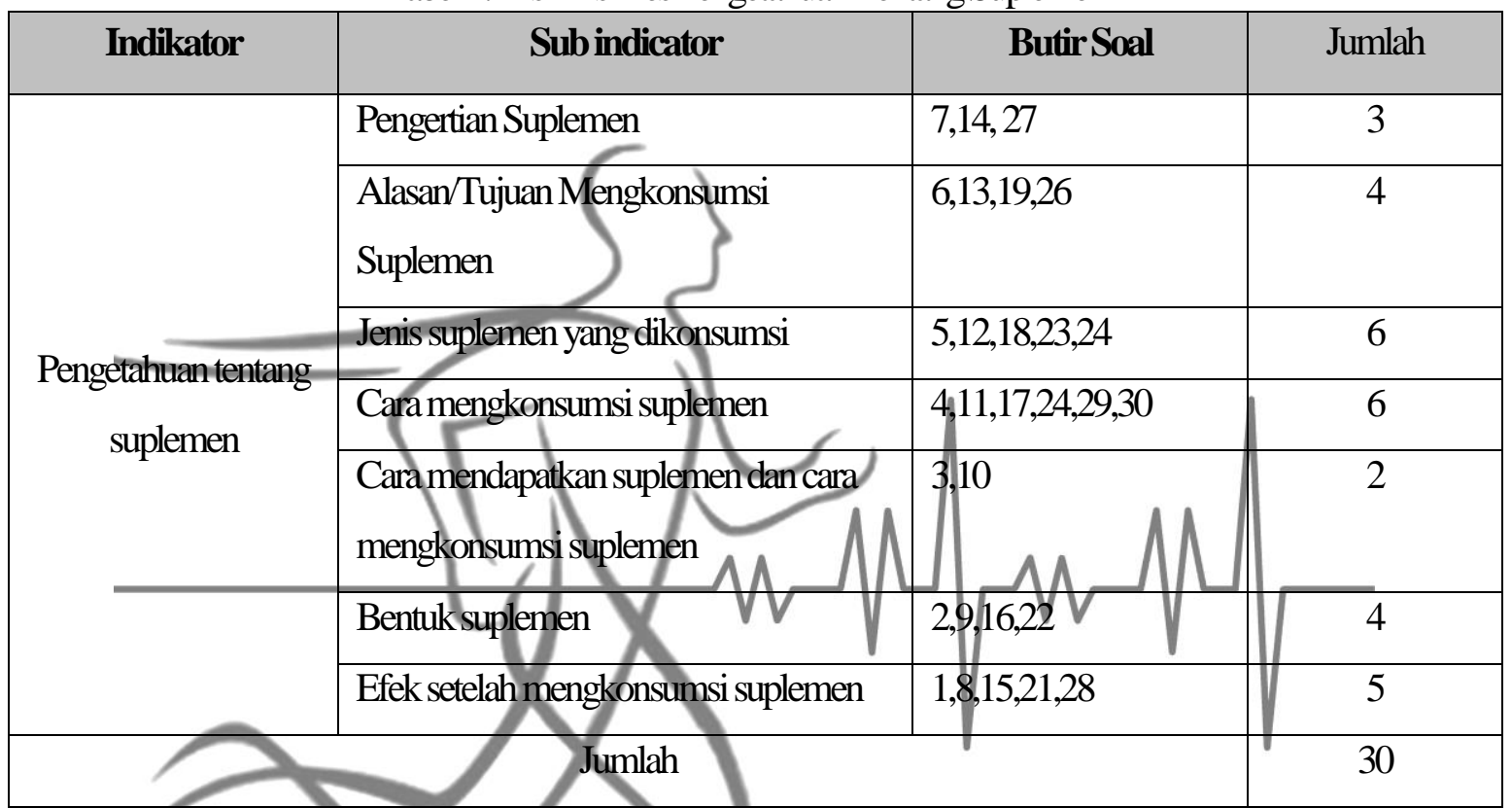

Sebelum angket dijadikan sebagai alat pengumpul data maka instrumen ini terlebih dahulu diujicobakan di luar tempat penelitian untuk mengetahui validitas tes, dan reliabilitas tes yang akan dilakukan di Kayama.

Untuk mengetahui pengetahuan tentang suplemen, contoh diketahui dengan menilai jawaban terhadap 30 pertanyaan tentang pengetahuan suplemen. Jawaban pilihan salah diberi skor 0 , sedangkan jawaban pilihan benar di beri skor 1 dengan total skor 30 .

Tekhnik analisis data yang digunakan adalah tekhnik persentase

$P=\frac{F}{N} X 100 \% \quad$ (Rosmala Dewi, 2010:38).

Keterangan :

$\mathrm{P} \quad=$ Persentase

$\mathrm{F} \quad=$ Frekuensi atau jumlah responden yang memilih

$\mathrm{N} \quad=$ Jumlah sampel penelitian

$100 \%=$ Nilai tetap 
Dasar penilaian terhadap pertanyaan yang diajukan, tingkat pengetahuan suplemen contoh dikelompokkan berdasarkan persentase skor yang diperoleh dibandingkan skor total (Khomsan, 2000: 79) yaitu:
a. tinggi : $>80 \%$
b. sedang : $60-80 \%$
c. rendah : $<60 \%$

\section{HASIL DAN PEMBAHASAN}

1. Hasil Penelitian

Berdasarkan hasil jawaban responden dari kuesioner terhadap 80 orang yang dijadikan sampel penelitian yang merupakan member fitness khususnya di fitness center New Life Gym, XI Fitness Center dan Grand Olympus Gym Center, diperoleh gambaran karakteristik tentang jenis kelamin, usia pendidikan, pekerjaan, konsumsi suplemen dan tingkat pengetahuan yang dapat dilihat di bawah ini.

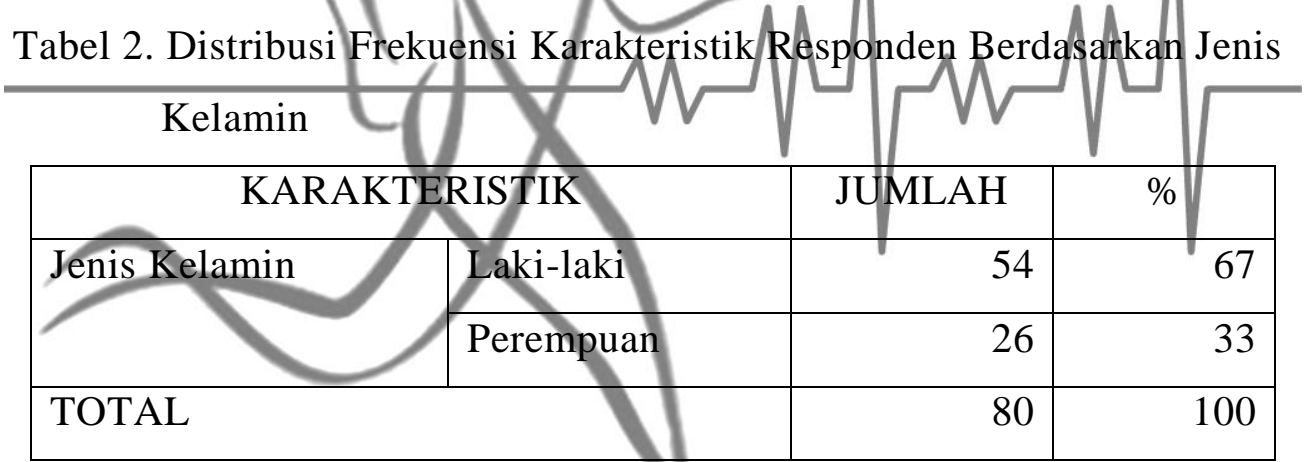

Berdasarkan tabel 2 di atas maka didapat jumlah responden yang berjenis kelamin laki-laki dari ketiga fitness centre adalah sebanyak 54 orang (67\%) dan responden yang berjenis kelamin perempuan adalah sebanyak 26 orang (33\%).

Tabel 3. Distribusi Frekuensi Responden Berdasarkan Usia

\begin{tabular}{|l|l|r|r|}
\hline \multicolumn{2}{|c|}{ KARAKTERISTIK } & JUMLAH & \multicolumn{1}{|c|}{$\%$} \\
\hline Usia & $<40$ tahun & 77 & 96 \\
\cline { 2 - 4 } & $>40$ tahun & 3 & 4 \\
\hline TOTAL & 80 & 100 \\
\hline
\end{tabular}

Berdasarkan Tabel 3 dapat dilihat bahwa yang menjadi responden dalam penelitian ini adalah yang berusia $<40$ tahun berjumlah 77 responden (96\%), responden yang berusia $>40$ tahun berjumlah 3 responden $(4 \%)$.

Berdasarkan hasil penelitian karakteristik responden berdasarkan tingkat pendidikan dapat dilihat pada tabel 4 di bawah ini. 


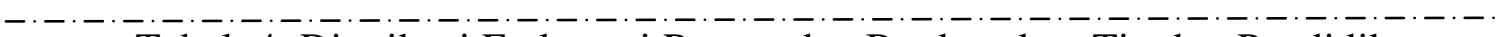
Tabel. 4. Distribusi Frekuensi Responden Berdasarkan Tingkat Pendidikan

\begin{tabular}{|l|l|r|r|}
\hline \multicolumn{2}{|c|}{ KARAKTERISTIK } & JUMLAH & \multicolumn{1}{|c|}{$\%$} \\
\hline Tingkat Pendidikan & SMA/SMK & 33 & 41 \\
\cline { 2 - 4 } & Diploma (D3) & 7 & 9 \\
\cline { 2 - 4 } & Sarjana (S1) & 40 & 50 \\
\cline { 2 - 4 } & Pascasarjana & - & \\
\hline TOTAL & 80 & 100 \\
\hline
\end{tabular}

Berdasarkan Tabel 4 dapat dilihat bahwa responden dalam penelitian ini dengan tingkat pendidikan SMA/SMK berjumlah 33 responden (41\%), tingkat pendidikan Diploma (D3) berjumlah 7 responden (9\%) dan pendidikan Sarjana (S1) berjumlah 40 responden $(50 \%)$.

Tabel 5. Distribusi Frekuensi Responden Berdasarkan Jenis Pekerjaan

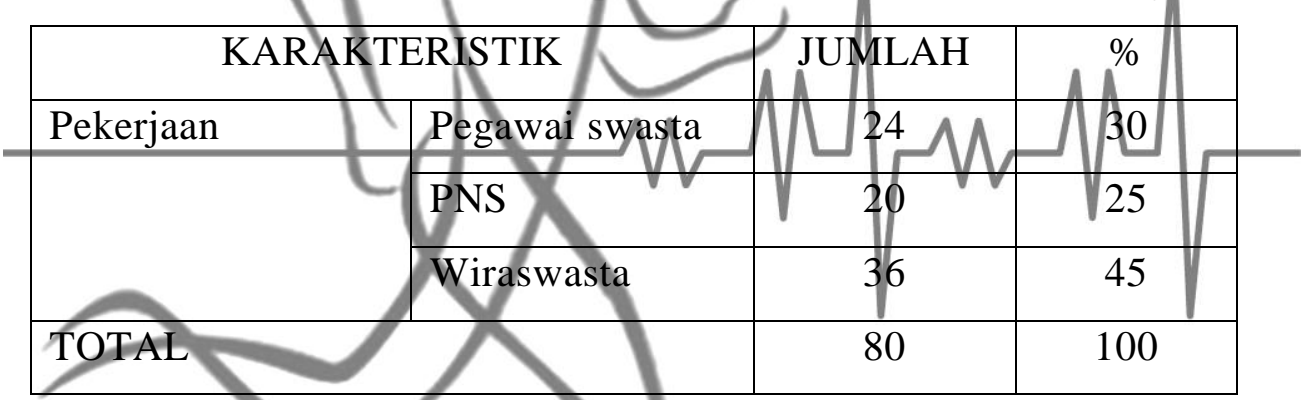

Berdasarkan Tabel 5 dapat dilihat bahwa responden dalam penelitian ini dengan status pegawai swasta berjumlah 24 responden (30\%), status Pegawai Negeri Sipil berjumlah 24 responden $(25 \%)$ dan responden dengan status wiraswasta berjumlah 36 responden (45\%).

Tabel 6. Distribusi Frekuensi Responden Berdasarkan Konsumsi Suplemen

\begin{tabular}{|l|c|c|}
\hline \multicolumn{1}{|c|}{ Konsumsi Suplemen } & Jumlah & Persentase \\
\hline 1 x sehari & 67 & 84 \\
\hline 2-3 x sehari & 13 & 16 \\
\hline TOTAL & 80 & 100 \\
\hline
\end{tabular}

Berdasarkan tabel 6 di atas maka dapat dilihat bahwa responden yang mengonsumsi suplemen sebanyak 1x sehari adalah sebanyak 67 orang (4\%), responden yang mengonsumsi suplemen sebanyak 2-3x sehari adalah sebanyak 13 orang $(16 \%)$. 
Tabel 7. Distribusi Frekuensi Responden Berdasarkan Tingkat Pengetahuan

\begin{tabular}{|l|c|c|}
\hline \multicolumn{1}{|c|}{ Tingkat Pengetahuan } & Jumlah & Persentase \\
\hline Tinggi $(>80)$ & 46 & $58 \%$ \\
\hline Sedang $(60-80)$ & 28 & $35 \%$ \\
\hline Rendah $(<60)$ & 6 & $7 \%$ \\
\hline TOTAL & 80 & 100 \\
\hline
\end{tabular}

Hasil distribusi frekuensi berdasarkan tingkat pengetahuan dari tabel 7 adalah sebagai berikut: sebanyak 46 responden $(46 \%)$ berada dalam tingkat pengetahuan kategori tinggi, sebanyak 28 responden $(35 \%)$ berada dalam tingkat pengetahuan sedang dan sebanyak 6 responden (7\%) berada dalam tingkat pengetahuan yang rendah.

\section{Pembahasan}

Berdasarkan data hasil penelitian Tingkat Pengetahuan Member Fitness Kota Medan dalam Mengkonsumsi Suplemen di fitness center New Life Gym, X 1 fitness center dan Gran Olympus Gym Center berada padd tingkat pengetahuan yang tinggi. Member fitness mengkonsumsi suplemen 1 kali/hari sebanyak 48 orang (58\%). Sedangkan member fitness yang mengkonsumsi 2-3 kali/hari sebanyak 13 orang (16\%). Menurut dari Barr (1986) (dalam Sarjono, 2010) yang menyatakan bahwa 64\% dari orang yang mengikuti kelas fitness menggunakan suplemen dan rata-rata mengonsumsi suplemen lebih dari dua suplemen perhari. Menurut Foote et al (2003), mereka yang melakukan olahraga dan menghasilkan keringat setidaknya 3 kali/minggu memiliki kecenderungan untuk mengonsumsi suplemen lebih-besar dibandingkan mereka yang tidak teratur untuk berolahraga.

Penambahan suplemen sebenarnya tidak diperlukan jika tingkat asupan protein yang berasal dari makanan saja sudah di atas kecukupan, tetapi dalam praktiknya konsumsi suplemen asam amino ini merupakan sesuatu hal yang dianggap wajib bagi para anggota fitness atau binaragawan. Penambahan dari suplementasi protein akan dibakar menjadi energi atau disimpan dalam bentuk lemak tubuh yang akan dijadikan cadangan energi di dalam otot sehingga dapat mencegah terjadinya kelemahan otot sewaktu latihan beban (Husaini, 2000). Suplemen dirancang bukan untuk menggantikan makanan. Bagaimanapun sebutir pil tidak akan dapat memberikan semua nutrient yang kita perlukan untuk hidup sehat. Sebagai contoh, dalam buah-buahan dan sayuran terdapat antioksidan yang berkhasiat melindungi tubuh terhadap penyakit, tetapi 
antioksiddan tersebut termasuk ke dalam jenis yang belum behasil diidentifikasi.Oleh karena itu, antioksidan ini tidak terdapat dalam pil (Daniel, 2014).

Usia responden didominasi oleh usia < 40 tahun yaitu sebesar 96\%. Hal ini sejalan dengan teori bahwa pada usia di bawah 40 tahun pada tubuh terjadi peningkatan denyut jantung yang berpengaruh terhadap daya tahan kardiovaskuler. Faktor lain yang mempengaruhi tingkat pengetahuan seseorang adalah tingkat pendidikan. Hasil penelitian ini didapat tingkat pendidikan sampel termasuk kategori tinggi yaitu pada tingkat sarjana (S1) sebanyak 40 orang (50\%).

Tingkat pendidikan mempengaruhi pola pikir dan wawasan terhadap ilmu pengetahuan dan teknologi. Buktinya adalah, dari hasil penelitian ini sebagian besar responden berpendidikan dan mampu mendefinisikan suplemen secara benar, yaitu sebesar 46 orang (58\%) memaknai suplemen sebágai produk keséhatan yang mengandung satu atau lebih zat yang bersifat nutrisi atau obat. Peran iklan, media elektronik maupun cetak berpengaruh sangat besat terhadap publikasi/dan pemahaman tentang suplemen. Hal ini dikarenakan, semakin mbdern peradaban manusia, sehingga manusia yang berpendidikan, berwawasan luas mampu dengan cepat memperoleh informasi tentang suplemen. Dari teknologi yang modern juga, responden dapat menentukan jenis suplemen mana yang aman dan baik untuk dikonsumsi.

Seorang olahragawan memerlukan energi untuk mempertahankan fungsi tubuh agar dapat berfungsi dengan baik, peredaran darah, persyarafan, pernafasan dan gerak otot sehingga dapat berlatih dan bertanding dengan baik. Sumber energi utama pada berbagai tingkat dan jenis aktifitas fisik berasal dari karbohidrat, lemak, dan protein yang berfungsi untuk mempertahankan aktifitas fungsional tubuh (Suniar, 2002). Protein dibutuhkan untuk pertumbuhan, perkembangan, pembentukan otot, pembentukan sel-sel darah merah.

Pekerjaan responden juga mempengaruhi responden dalam melakukan olahraga. Sebagian besar responden bekerja sebagai wiraswasta yaitu sebanyak 36 orang (46\%), dapat diduga mereka tidak memiliki jam kerja yang ketat sehingga masih mempunyai waktu luang yang cukup untuk menjadi member guna menjaga kesehatannya jika dibandingkan dengan pegawai swasta dan pegawai negeri sipil.

Dari pengalaman dan penelitian, ternyata perilaku yang didasari oleh pengetahuan akan lebih baik dibandingkan perilaku yang tidak didasari oleh 
pengetahuan karena didasari oleh kesadaran, rasa tertarik, dan adanya pertimbangan dan sikap positif.

\section{KESIMPULAN}

Berdasarkan hasil penelitian maka didapat tingkat rata-rata pengetahuan member fitness centre di Kota Medan dalam mengonsumsi suplemen berada dalam kategori tinggi yaitu $84 \%$.

\section{DAFTAR PUSTAKA}

Adrian, Daniel. (2014). Perfect Six Pack Kiat Ampuh Membentuk Tubuh Ideal. Sleman. Second Hope

Gunawan, A. (2002). Food Combining: Makanan Serasi, Pola Makan untuk Langsing dan Sehat. Jakarta: PT. Gramedia Pustaka Utama.

Irianto, J. (2007). Panduan Gizi Lengkap Keluarga dan Olahragawan. Yogyakarta: Andi Offset. Notoatmodjo. (2010). Pengetahuan Umum. Jakarta : Rinerka Cipta.

Foote, et al. (2003). FactorAssociated With Dietary Supplement Use Among Healthy Adults of Five Ethnicties The Multiethic Cohort Study. American Journal of Epidemiology.

Husaini,MA. (2000). Kebutuhan Protein Mntuk Berprestasi Optimal dalam Pedoman Pelatihan Gizi Olahraga untuk Prestasi. Depkes RI, Dirjen Kesehatan Masyarakat Direktorat Gizi Masyarakat.

Sarjono, Ajeng Hadiati. (2010). Faktor-faktor yang Berhubungan dengan Konsumsi Suplemen Makanan Pada Mahasiswa Rumpun Kesehatan dan Non-Kesehatan di UI. Skripsi Fakultas Kesehatan Masyarakat. Universitas Indonesia, Depok. 